\title{
Effects of land use on benthic macroinvertebrate communities: Comparison of two mountain streams in Korea
}

\author{
Yung-Chul Jun ${ }^{1}$, Nan-Young Kim ${ }^{1}$, Soon-Jik Kwon ${ }^{2}$, Seung-Chul Han ${ }^{2}$, In-Chul Hwang ${ }^{2}$, \\ Jae-Heung Park ${ }^{2}$, Doo-Hee Won ${ }^{2}$, Myeong-Seop Byun ${ }^{3}$, Hak-Yang Kong ${ }^{3}$, Jong-Eun Lee ${ }^{4}$ \\ and Soon-Jin Hwang ${ }^{1 *}$ \\ ${ }^{1}$ Department of Environmental Science, Konkuk University, Seoul 143-701, Republic of Korea \\ 2 Doohee Institute of Ecological Research, Korea Ecosystem Service Inc., Seoul 153-768, Republic of Korea \\ ${ }^{3}$ Water Environment Research Department, The National Institute of Environmental Research, Inchon 404-170, Republic of Korea \\ ${ }^{4}$ Department of Biological Science, Andong National University, Andong 760-749, Republic of Korea
}

Received 31 August 2010; Accepted 2 March 2011

\begin{abstract}
Anthropogenic land use within watersheds has substantial effects on aquatic habitats and biological communities. From September 2006 to December 2008, we investigated the effects of land use on benthic macroinvertebrate communities by comparing Song Stream and Odae Stream, two adjacent mountain streams in Korea whose watersheds have different land use patterns. Song Stream is significantly disturbed by agricultural activities in the watershed, whereas Odae Stream is relatively undisturbed and is surrounded by a well-conserved forest area. Song Stream had significantly higher levels of all nutrients and sedimentrelated factors due to the adjacent agricultural area. As a result, Song Stream had markedly lower species community indices, such as taxa richness and abundance. In Song Stream, macroinvertebrate scrapers and predators were most adversely affected, whereas collector-gatherers became a dominant group. Based on correlation and multivariate analyses, total dissolved solids had the strongest negative relationship with macroinvertebrate assemblages, followed by electrical conductivity, total nitrogen, and $\mathrm{pH}$. The proportion of cobble in stream substrate was positively related to the richness and abundance of macroinvertebrates. Our results indicate that disturbances caused by agricultural land use, particularly sand deposition, had significant adverse effects on macroinvertebrate habitats and on the biotic integrity of benthic macroinvertebrate communities.
\end{abstract}

Key words: Benthic macroinvertebrates / mountain stream / land use / sediment / biotic integrity

\section{Introduction}

Land use is a major concern throughout the world because it is associated with disturbances that lead to soil erosion, sedimentation, nutrient enrichment, and input of toxic substances to aquatic habitats and biological communities (Rier and King, 1996; Stewart et al., 2001; Brierley and Fryirs, 2005). Such disturbances can directly or indirectly harm water quality and channel morphology and ultimately disrupt the biological properties of stream ecosystems (Cooper, 1993).

Abundant research has documented the negative effects of agricultural land use on stream ecosystems, and has shown that diffuse pollution from agricultural

\footnotetext{
*Corresponding author: sjhwang@konkuk.ac. kr
}

regions is a principal non-point source of sediment and nutrients (Harding et al., 1999; Quinn and Stroud, 2002). Clearing of riparian vegetation for tilling increases the vulnerability to surface runoff and this can lead to high concentrations of nutrients and explosive increases in algal growth (Ulrich et al., 1993). Increased sediment also has deleterious effects, although nutrients and sediments can interact synergistically (Lemly, 1982) or differentially.

The best-known adverse consequence of agriculture on watersheds is the large amount of sediment exported into adjacent rivers and streams (Wood and Armitage, 1997; Suren and Jowett, 2001). Sedimentation in lotic ecosystems is generally accompanied by deterioration in water quality, reduced light penetration, and the filling of interstitial spaces in benthic substrates (Wood and Armitage, 1997; Crétaz and Barten, 2007). Streambed degradation 

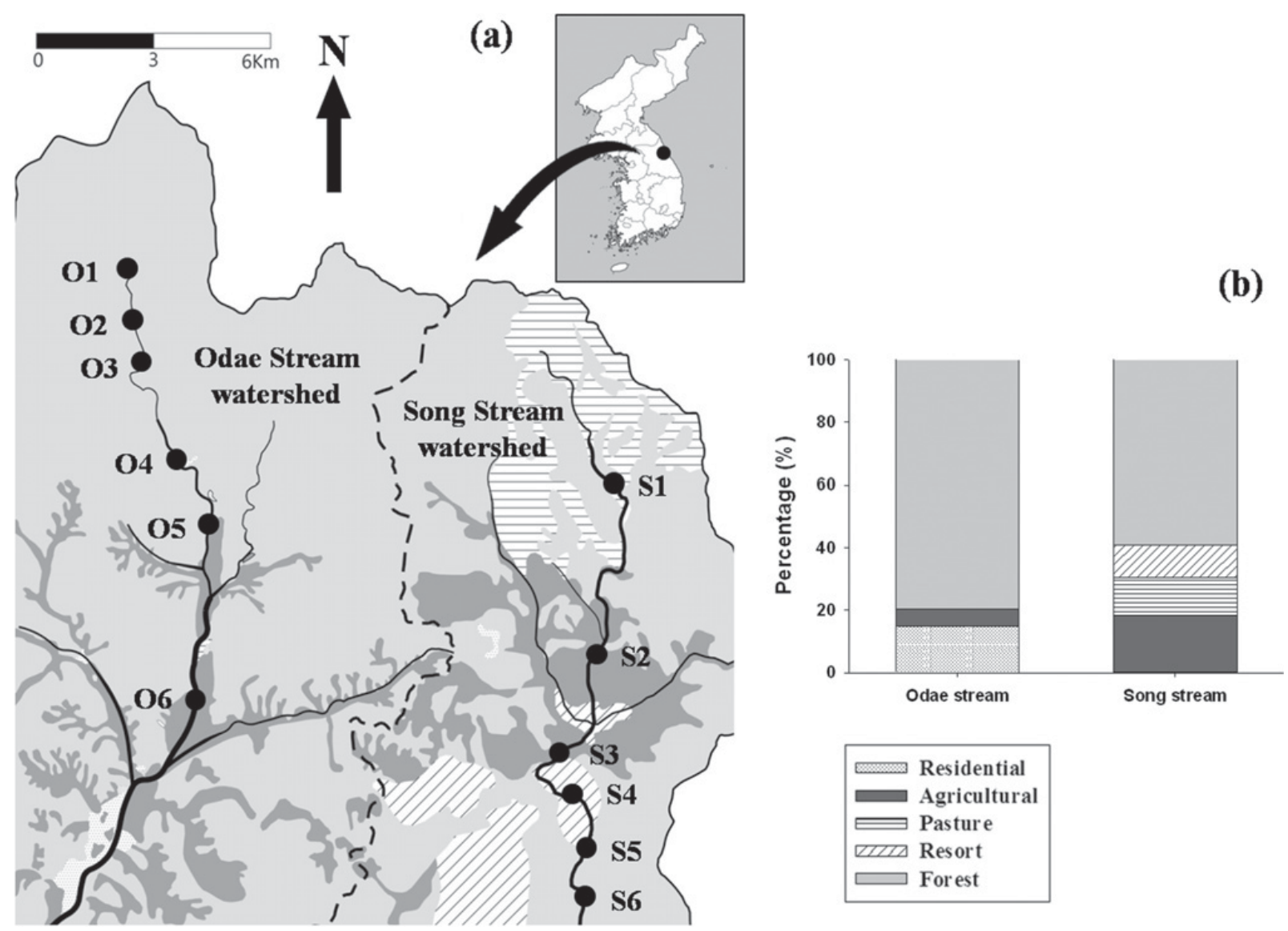

Fig. 1. (a) Map of the watersheds of the Odae Stream (O1-O6) and Song Stream (S1-S6), showing six sampling sites (black circles) along longitudinal gradients in each stream and the watershed boundaries (dotted line). (b) Types of land use in each watershed.

by sedimentation can ultimately result in the extinction of benthic macroinvertebrates (Waters, 1995), because these organisms predominantly dwell on stream substrates and require specific geomorphological structures for completion of oviposition and other life cycle stages (Merritt and Cummins, 1996). Thus, the overall success of diverse benthic macroinvertebrate communities is strongly dependent on the integrity of their physical environments (Karr et al., 1986). Previous studies have documented multiple adverse effects of sedimentation on benthic macroinvertebrates (Ryan, 1991; Wood and Armitage, 1997; Bilotta and Brazier, 2008), such as a decline in species diversity and density (Quinn et al., 1992), a reduction in the number of suitable habitats (Chutter, 1969), declines in food resources and food quality (Broekhuizen et al., 2001), a reduction in feeding and respiration (Lemly, 1982), and increases in drift rates (Suren and Jowett, 2001).

In the present study, we examined the effects of mixed land use on the benthic macroinvertebrate communities in mountain streams of Korea. In particular, we compared the physico-chemical characteristics and benthic macroinvertebrate communities of Odae Stream, whose watershed is well-preserved, with those of Song Stream, whose watershed has been disturbed by significant agricultural development.

\section{Materials and methods}

\section{Study area}

Benthic macroinvertebrates were collected at six sites from Song Stream and six sites from Odae Stream (Fig. 1), both of which are tributaries of the Namhan River. Both streams are located at the mid-eastern alpine area of the Korean peninsula (Baekdudaegan), and flow south before joining the Namhan River. They occur in V-shaped valleys with narrow floodplains in the valley bottoms along the upstream regions and have similar physiographic characteristics. The weather of both stream watersheds is characterized by relatively cold winters and cool summers. The average temperature was $7.2^{\circ} \mathrm{C}$ in 2008 and the annual precipitation of $1129 \mathrm{~mm}$ occurs throughout the year, but tends to be lower in early spring (March) and autumn (September to November) than in summer (June to early September) and winter (January and December), which has a lot of snow (KMA, 2009).

Song Stream has a total length of $81.4 \mathrm{~km}$ and a drainage area of $352.1 \mathrm{~km}^{2}$. Its watershed can be divided into three geomorphological areas according to the type of land use: (i) an open pastureland for cattle grazing and sightseeing at the headwaters and upstream region; (ii) a wide range of highland agriculture from the upper to 
middle region; and (iii) residential areas and large resort facilities in the lower region (Fig. 1). Song Stream was impounded to form a $2.2 \mathrm{~km}^{2}$ reservoir, Lake Doam, that has a storage capacity of $5100 \mathrm{~m}^{3}$ about $24 \mathrm{~km}$ downstream from source (MOE/HERC, 2010).

Previous studies have indicated that highland agricultural activities performed on a steep slope, such as the Song Stream basin, can trigger significant soil erosion and nutrient enrichment (Delong and Brusven, 1998; Miserendino and Pizzolon, 2004). Although the water of this stream is usually clean and has many of the physiographical properties of an alpine stream, its basin has long been plagued by habitat destruction and water quality deterioration, particularly after heavy storms and the spring melting season. Furthermore, the subcatchment of a tributary at the downstream region has recently suffered from activities related to the construction of another large resort and service complex, which intensified physical disturbance due to the flushing of severely turbid waters and sediments. Consequently, there has been great interest in improving the water quality and restoration of the Song Stream watershed by management of non-point source pollution (MOE, 2007).

In contrast, Odae Stream (56.6 km in length, $451.7 \mathrm{~km}^{2}$ catchment area) is well-preserved and has a very low level of watershed disturbance, except for the downstream region which has adjacent agricultural activities and residential areas. Disruptions due to land use are limited by environmental protection laws in the upper region, which is in Mt. Odae National Park. The valleys in this stream are fully or partially shaded by riparian vegetation. Riparian forests are mainly composed of a variety of forest tree species, including common oak (Quercus mongolica Fischer), needle fir (Abies holophylla Max.), cottonwood (Populus koreana Rehder), amur linden (Tilia amurensis Rupr.), Korean willow (Salix koreensis Andersson), and Manchurian fullmoon maple (Acer pseudosieboldianum (Pax.) Kom.).

\section{Measurements of environmental factors}

Substrate composition of benthic habitats was determined by visual examination of the coverage of each particle size class across a $10 \mathrm{~m}$ wide transect at sampling reach of each site during each field survey. Substrate composition was divided into five classes based on the modified Wentworth scale (Cummins, 1962): boulder (>256 $\mathrm{mm}$ diameter), cobble (64-256 $\mathrm{mm}$ diameter), pebble (16-64 mm diameter), gravel (2-16 $\mathrm{mm}$ diameter), and sand $(<2 \mathrm{~mm}$ diameter $)$.

From June 2007 to December 2008 (except the winter of 2007), stream water was sampled seasonally for measurement of water chemistry parameters, resulting in six datasets for each stream. Water temperature, $\mathrm{pH}$, electrical conductivity (EC), dissolved oxygen (DO), turbidity, and total dissolved solids (TDS) were measured in the field using a multi-probe meter (Horiba U-22XD, Japan). Water samples (2 L) were collected in sterile plastic bottles at each site, and transported to the laboratory on ice. Laboratory measurements were used to determine biochemical oxygen demand (BOD), suspended solids (SS), chlorophyll- $a(\mathrm{Chl}-a)$, total nitrogen (TN), and total phosphorus (TP) concentrations following standard American Public Health Association (APHA) methods (APHA, 2001).

The proportions of the different types of land use in each watershed were determined from a digital land use/ land cover map obtained from the Ministry of Environment (Korea). This map was generated using Landsat Thematic Mapper (TM; $30 \mathrm{~m}$ resolution) and Indian Remote Sensing (IRS)-1C pan-chromatic (5.8 m resolution) images taken in 2007. The five land use categories were forest, pasture, agriculture, residential, and resort.

\section{Benthic macroinvertebrate sampling}

Benthic macroinvertebrates were collected seasonally at six sample sites of each stream on eight occasions from September 2006 to December 2008. There was no sampling during the winter of 2006/2007 because of freezing conditions. Benthic macroinvertebrates were quantitatively sampled at riffle habitats using a Surber sampler $(30 \mathrm{~cm} \times 30 \mathrm{~cm}$, mesh $1 \mathrm{~mm})$. Three samples at each site were taken from randomly selected riffles in the stream channel, along a 50-100 $\mathrm{m}$ reach, and then pooled together in a $500 \mathrm{~mL}$ plastic bottle. The collected materials were preserved by the addition of $80 \%$ ethanol, and transported to the laboratory for further analysis. This sampling procedure was based on the guidelines of the "National biological surveys for stream ecosystem health" in Korea (MOE/NIER, 2008).

All organisms were completely separated from detritus and small substrate particles within two weeks without subsampling, except for Oligochaetes and Chironomidae. Individual specimens were transferred to $10 \mathrm{~mL}$ bottles for identification. Macroinvertebrate specimens were examined under light microscopy $(100 \times$ magnification; Leica MZ7 dissecting microscopes) and identification was conducted to the lowest feasible level, typically species or genus, except for Diptera, which were classified at the subfamily or genus level. Non-insects (Platyhelminthes, Nematomorpha, Mollusca, Annelida, and Crustacea) were identified according to Kwon et al. (2001) and Smith (2001), and aquatic insects according to Yoon (1995), Merritt and Cummins (1996), and Won et al. (2005). Chironomid larvae from all samples were arbitrarily differentiated into six groups based on morphotype, because there are no definitive guidelines for their classification in Korea. All individuals were counted after identification.

\section{Data analysis}

The density of benthic macroinvertebrates was calculated as individuals per square meter. The community 
Table 1. List of eight metrics used to characterize BIBI and expected responses to increased anthropogenic disturbance. BIBI was measured by summing the scores of the eight metrics (from Barbour et al., 1999; MAF, 2007).

\begin{tabular}{|c|c|c|c|c|c|c|}
\hline \multirow[b]{2}{*}{ Metric } & \multirow[b]{2}{*}{ Metric definition } & \multirow{2}{*}{$\begin{array}{l}\text { Expected response } \\
\text { to increasing } \\
\text { disturbance }\end{array}$} & \multicolumn{4}{|c|}{ Scoring criteria } \\
\hline & & & 6 & 4 & 2 & 0 \\
\hline Taxa richness & Number of species in a sample & Decline & $>80 \%$ & $60-80 \%$ & $40-60 \%$ & $<40 \%$ \\
\hline EPT richness & $\begin{array}{l}\text { Number of EPT (mayfly, stonefly, } \\
\text { and caddisfly) species in a sample }\end{array}$ & Decline & $>80 \%$ & $65-80 \%$ & $50-65 \%$ & $<50 \%$ \\
\hline Total abundance & Total number of individuals in a sample & Decline or variable & $>80 \%$ & $60-80 \%$ & $40-60 \%$ & $<40 \%$ \\
\hline $\begin{array}{l}\text { Ratio of EPT to } \\
\text { Chironomidae } \\
\text { abundance }\end{array}$ & $\begin{array}{l}\text { Ratio of pollution-sensitive EPT taxa } \\
\text { to pollution-tolerant } \\
\text { Chironomidae abundance }\end{array}$ & Decline & $>75 \%$ & $50-75 \%$ & $25-50 \%$ & $<25 \%$ \\
\hline Diversity index $\left(H^{\prime}\right)$ & $\begin{array}{l}\text { Shannon diversity index (Shannon } \\
\text { and Weaver, 1949) }\end{array}$ & Decline & $>3$ & $2-3$ & $1-2$ & $<1$ \\
\hline $\begin{array}{l}\text { Species richness } \\
\text { index }(\mathrm{R} 1)\end{array}$ & $\begin{array}{l}\text { Margalef species richness index } \\
\text { (Margalef, 1958) }\end{array}$ & Decline & $>3$ & $2-3$ & $1-2$ & $<1$ \\
\hline ESB index & $\begin{array}{l}\text { Sum of assigned ecological scores for } \\
\text { each occurring species in the benthic } \\
\text { macroinvertebrate community }\end{array}$ & Decline & $>80$ & $60-80$ & $40-60$ & $<40$ \\
\hline $\begin{array}{l}\text { Ratio of CF and SC } \\
\text { to total abundance }\end{array}$ & $\begin{array}{l}\text { Ratio of collector-filterer (CF) and } \\
\text { scraper (SC) individuals to } \\
\text { total abundance }\end{array}$ & Decline & $>50 \%$ & $35-50 \%$ & $20-35 \%$ & $<20 \%$ \\
\hline
\end{tabular}

structures of benthic macroinvertebrates at both streams were evaluated in terms of total taxa richness, taxa abundance, number of species, density of EPT taxa (Ephemeroptera, Plecoptera, and Trichoptera; indicators of clean water), percentage of EPT density, relative frequency of individuals in the two major taxa, and Shannon diversity index (Shannon and Weaver, 1949; Rosenberg and Resh, 1993; Barbour et al., 1999).

Taxa were assigned into functional feeding groups (FFGs) and functional habit groups (FHGs), although there was some overlap in certain species due to changes in modes of feeding and habits over their life cycles (Merritt and Cummins, 1996; Smith, 2001). The five FFGs were collector-gatherers, collector-filterers, scrapers, shredders, and predators; the five FHGs were burrowers, climbers, clingers, sprawlers, and swimmers (Merritt and Cummins, 1996).

For the assessments of biotic integrity and habitat conditions, the Korean saprobic index (KSI) and the modified benthic macroinvertebrate index of biological integrity (BIBI) (MOE/NIER, 2006) were used. The KSI was developed from the saprobic valency concept (Zelinka and Marvan, 1961) by application of DIN 38410 in Germany (DIN 38410, 1990). This index is currently being used for a nationwide assessment of stream ecosystem health that is supervised by the Ministry of Environment (Korea). The KSI indicates the effect of organic pollution on water quality for mid- and long-term periods by use of the saprobic value and weighting factors for the 100 major benthic macroinvertebrate indicator groups. Won et al. (2006) provide detailed information on the KSI.

The BIBI, a comprehensive and multimetric index based upon research by Kerans and Karr (1994) and Barbour et al. (1999), was used to evaluate stream biotic integrity. A previous study tested candidate metrics and proposed the most suitable metrics for mountain streams in Korea (MAF, 2007). A total of eight metrics were applied to BIBI: taxa richness, EPT taxa richness, total abundance, ratio of EPT to Chironomidae abundance, Shannon diversity index, Margalef species richness index, ecological score of benthic macroinvertebrate community (ESB, which indicates aquatic environmental quality by multiplication of each environmental quality score of individual taxa by species frequency (MOE, 2000)), and ratio of collector-filterers and scrapers to total abundance (Table 1).

\section{Statistical analysis}

The significance levels of differences in environmental conditions and community indices of Odae Stream and Song Stream were assessed by independent $t$-tests. Spearman's rank correlation coefficients were calculated for analysis of the relationships of physical, chemical, and biological factors. Correlation analysis and $t$-tests were performed with STATISTICA (StatSoft, 2004).

Six datasets from sampling performed between June 2007 and December 2008 were analyzed by multivariate analysis. Benthic macroinvertebrate communities were classified using hierarchical cluster analysis with a flexible beta linkage method that used the Sørensen distance measure. Multi-response permutation procedures (MRPPs) were used to determine if there were significant differences among clusters. The same data were also analyzed by canonical correspondence analysis (CCA) to identify the relationships of environmental variables. Cluster analysis, CCA, and MRPP were conducted using PC-ORD software (version 4.25; McCune and Mefford, 1999). In the CCA, rare taxa (less than $0.1 \%$ of total 
Table 2. Summary of mean (standard deviation) of environmental variables at Odae Stream and Song Stream. Chemical variables were measured from June 2007 to December 2008 and a total of six datasets were collected. $P$-values indicate statistical significance based on independent $t$-tests.

\begin{tabular}{|c|c|c|c|c|c|}
\hline \multirow[b]{2}{*}{ Variables } & \multicolumn{2}{|c|}{ Odae Stream $(n=36)$} & \multicolumn{2}{|c|}{ Song Stream $(n=32)$} & \multirow[b]{2}{*}{$P$} \\
\hline & Mean & Range & Mean & Range & \\
\hline$\%$ Cobble & $60.6(7.1)$ & $40-70$ & $26.2(14.3)$ & $0-50$ & $<0.001$ \\
\hline$\%$ Sand & $1.9(5.2)$ & $0-20$ & $25.6(12.7)$ & $0-60$ & $<0.001$ \\
\hline Water temperature $\left({ }^{\circ} \mathrm{C}\right)$ & $12.1(6.1)$ & $1.3-24.9$ & $14.4(6.6)$ & $1.7-24.5$ & 0.132 \\
\hline $\mathrm{pH}$ & $7.4(0.5)$ & $6.4-8.2$ & $8.3(0.6)$ & $7.0-9.4$ & $<0.001$ \\
\hline $\mathrm{EC}\left(\mathrm{mS} . \mathrm{m}^{-1}\right)$ & $4.7(1.1)$ & $3.7-7.4$ & $13.4(6.6)$ & $3.9-23.6$ & $<0.001$ \\
\hline $\mathrm{BOD}\left(\mathrm{mg} . \mathrm{L}^{-1}\right)$ & $1.18(0.37)$ & $0.56-2.25$ & $1.41(0.63)$ & $0.27-2.99$ & 0.082 \\
\hline $\mathrm{DO}\left(\mathrm{mg} \mathrm{L}^{-1}\right)$ & $9.57(1.12)$ & $7.40-12.10$ & $9.85(1.46)$ & $7.45-12.60$ & 0.375 \\
\hline Turbidity (NTU) & $2.1(3.8)$ & $0-21.9$ & $59.3(112.0)$ & $0.1-589.0$ & 0.007 \\
\hline $\mathrm{SS}\left(\mathrm{mg} \cdot \mathrm{L}^{-1}\right)$ & $1.9(2.7)$ & $0-15.2$ & $22.1(47.1)$ & $0.6-181.0$ & 0.022 \\
\hline $\operatorname{TDS}\left(\mathrm{g} \cdot \mathrm{L}^{-1}\right)$ & $0.03(0.01)$ & $0.02-0.05$ & $0.09(0.04)$ & $0.03-0.15$ & $<0.001$ \\
\hline Chl- $a\left(\mu \mathrm{g} . \mathrm{L}^{-1}\right)$ & $0.56(0.63)$ & $0.0-2.88$ & $2.02(1.70)$ & $0.12-7.05$ & $<0.001$ \\
\hline $\mathrm{TN}\left(\mathrm{mg} \cdot \mathrm{L}^{-1}\right)$ & $1.33(1.02)$ & $0.34-4.64$ & $3.34(2.11)$ & $0.18-7.49$ & $<0.001$ \\
\hline $\mathrm{TP}\left(\mathrm{mg} . \mathrm{L}^{-1}\right)$ & $0.025(0.039)$ & $0.001-0.175$ & $0.106(0.178)$ & $0.008-0.834$ & 0.017 \\
\hline
\end{tabular}

assemblage abundance) were excluded, and six chironomid groups were unified into a Chironomidae spp. because of uncertain identification. After removing rare taxa and redundancy of environmental factors, 68 of 128 species (Appendix 1) and 12 physico-chemical environmental factors (water temperature, $\mathrm{pH}, \mathrm{EC}, \mathrm{DO}$, turbidity, SS, TDS, Chl- $a$, TN, TP, percent cobble, and percent sand) were used for CCA. Monte-Carlo simulations with 199 permutations were used to verify the statistical significance of computed canonical axes.

\section{Results}

\section{Environmental factors}

There were significant differences in the physicochemical parameters of Song Stream and Odae Stream. Song Stream had significantly higher $\mathrm{pH}, \mathrm{EC}$, turbidity, TDS, SS, Chl- $a$, TN, TP, and percent sand ( $t$-test, $P<0.01$ for all parameters) (Table 2); however, water temperature, DO, and BOD were not significantly different. This indicates a significant effect of discharge of nutrient-rich sediment from the watershed into Song Stream. Such nutrient- and sediment-related factors increased along a longitudinal gradient in Song Stream. In particular, maximum turbidity was recorded at site S5 (589 NTU) in June 2008, which was about 260-fold higher than in Odae Stream (2.3 NTU on average) at the same time. SS was in the range of $144-181 \mathrm{mg} . \mathrm{L}^{-1}$ in the middle region of Song Stream (S3-S5) in June 2007 and was 44- to 55-fold higher than the mean SS of Odae Stream.

Complex substrate composition, which provides diverse benthic habitats, was also very different between the two streams (Fig. 2). The substrate in Odae Stream was mostly cobbles and pebbles, with limited sand, whereas the substrate in Song Stream had high levels of sand and granules, corresponding to an increased amount of small substrates.
Correlation analysis of environmental factors indicated that measures of nutrient-related factors increased as turbidity, TDS, and SS increased. The level of SS was significantly correlated with Chl- $a(r=0.618, P<0.01)$, TN $(r=0.450, P<0.01)$, and TP $(r=0.935, P<0.01)$, and EC was also positively correlated with turbidity, TDS, SS ( $r=0.397,0.997$, and 0.410 , respectively, $P<0.01$ for all), and nutrients $(r=0.797$ for TN, $r=0.452$ for TP, $P<0.01$ for both). The percentage of cobble in substrates was negatively correlated with chemical variables, particularly TDS, EC, TN, and $\mathrm{pH}(r=-0.761,-0.754,-0.671$, and -0.643 , respectively, $P<0.01$ for all). On the contrary, $\mathrm{pH}, \mathrm{EC}$, turbidity, and sediment- and nutrientrelated factors increased as the percent of sand in substrates increased (opposite to the effect of cobble). This indicates that agricultural land use in the Song Stream watershed had detrimental effects on the environment of Song Stream.

\section{Benthic macroinvertebrate communities}

During the entire study period, 134 species of benthic macroinvertebrates, mainly aquatic insects, were identified in both streams. Ephemeroptera (36 species), Trichoptera (33), Diptera (29), and Plecoptera (25) were the most common taxonomic orders. Total taxa richness and taxa richness per sample were significantly higher in Odae Stream (119 and 36.2, respectively) than in Song Stream (99 and 19.7, respectively) (independent $t$-test, $P<0.01$ ). EPT taxa richness per sample was 27.7 in Odae Stream and 13.3 in Song Stream.

The total taxa richness and EPT richness of the two streams were also different (Fig. 3). The taxa richness of Odae Stream ranged from 28.9 to 41.0 species and had little variation, although there was a slight decrease at site O6; the taxa richness of Song Stream was markedly lower in downstream regions. There were also differences in taxa abundance. The mean density of Odae Stream ranged 


\section{(a) Odae Stream}

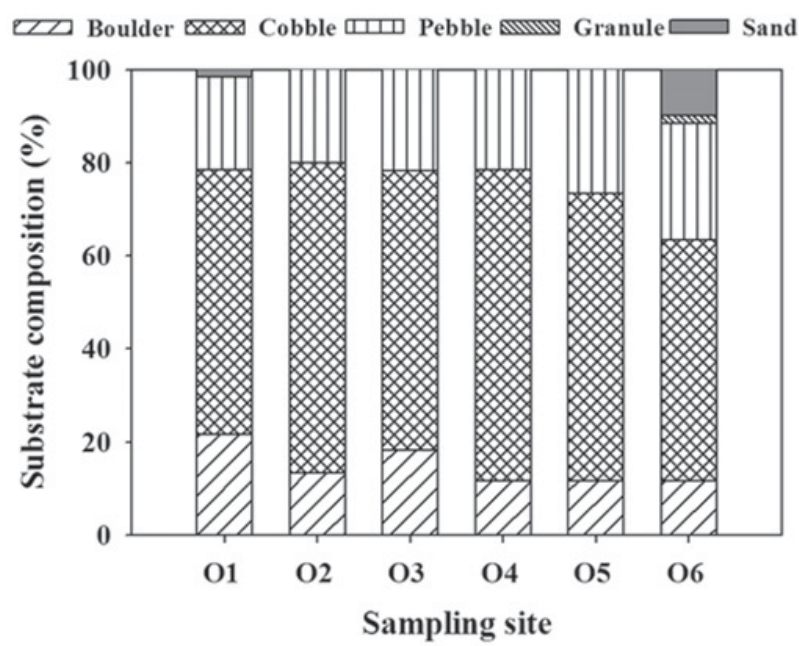

(b) Song Stream

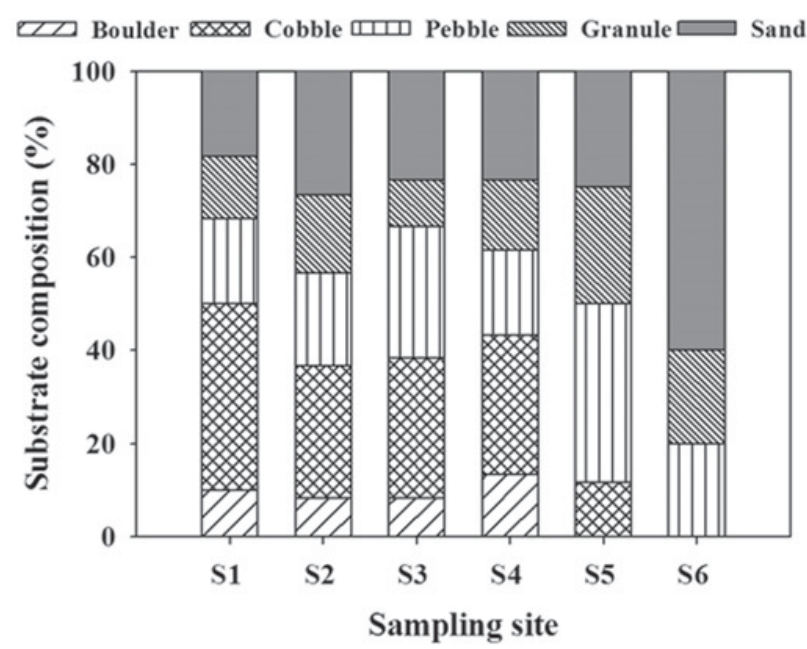

Fig. 2. Percentage of substrate composition at each sampling site of Odae Stream (a) and Song Stream (b). Substrates were divided into five categories by particle size, based on the modified Wentworth scale (Cummins, 1962): boulder, cobble, pebble, granule, and sand.

from 3620 individuals.m ${ }^{-2}$ (site O5) to 4219 individuals. $\mathrm{m}^{-2}$ (site O6), with no distinct differences among sampling sites and no seasonal variations (Fig. 3a). In contrast, the taxa abundance at Song Stream declined from 3584 individuals.m $^{-2}$ at site $\mathrm{S} 1$ to 394 individuals. $\mathrm{m}^{-2}$ at site S6 (Fig. 3b).

In Song Stream, taxa richness, EPT taxa richness, and taxa abundance were significantly different among the six sites $\left(\right.$ ANOVA: $F_{\text {richness }}=30.3, F_{\mathrm{EPT}}$ taxa $=41.3, F_{\text {density }}=$ $4.2, P<0.0001)$. Taxa richness at sites $\mathrm{S} 4, \mathrm{~S} 5$, and $\mathrm{S} 6$ was almost four-fold lower than that at site S1. However, there were no significant differences among seasons (ANOVA: $P_{\text {richness }}=0.41$ and $\left.P_{\text {EPT taxa }}=0.60\right)$ except for density, indicating that density in the autumn was significantly lower than in other seasons, but was higher in winter (ANOVA: $F_{\text {density }}=5.3, P_{\text {density }}=0.002$ ).
Relative to Odae Stream, dominance was higher and Shannon diversity and Margalef species richness indices were lower in Song Stream. This is presumably because the increase in sand coverage due to sedimentation led to a benthic habitat with homogeneous substrates, and this reduction of habitat heterogeneity severely reduced the diversity and abundance of macroinvertebrates.

Total taxa richness, EPT taxa richness, percent EPT to total abundance, and Shannon diversity and Margalef species richness indices were negatively correlated with the number of physico-chemical environmental factors and a higher percent sand coverage. However, these parameters were positively correlated with percent cobble $(P<0.01)$ (Table 3). The dominance index was positively correlated with higher levels of all environmental factors, except for percent cobble.

\section{Functional feeding and habit groups}

In Odae Stream, scrapers were the dominant FFG group, and there were relatively large numbers of scraper species and individuals at all sites, with an average of about $46 \%$ of the total density (Fig. 4a). The number of predator species was also high $(27 \%)$ at all sites of Odae Stream, mainly due to diverse Plecoptera, Athericidae (Diptera), and Rhyacophilidae (Trichoptera), despite a low mean abundance $(9 \%)$. In contrast, Song Stream had low species richness $(11 \%)$ and a low density of predators $(3 \%)$. However, Song Stream had high taxa richness $(49 \%)$ and an abundance of collector-gatherers $(59 \%)$, with maxima in the midstream regions (Fig. 4b). The most abundant collector-gatherer groups were Tubificidae (Annelida), Baetidae (Ephemeroptera), and Chironomidae (Diptera). Analysis of the relationship between substrate composition and FFG indicated that taxa richness and abundance of FFGs substantially decreased as the percent of sand coverage increased (Spearman rank correlation, $P<0.05$ ). There was, however, a strong positive correlation in percentage of species numbers and density in collector-gatherers as the percent sand increased, despite drops in taxa richness and abundance (Table 4). Collector-filterers were weakly associated with substrate composition.

Among FHGs, clingers and sprawlers were overwhelmingly the most diverse groups in both streams, due to the physical properties of these mountain streams. The density of clingers in Song Stream was maximal at S1 $(82 \%$ average) and gradually declined to downstream site S5 $(36 \%)$ (Fig. 4b); in Odae Stream, there was no change in taxa richness and abundance of this group among the different sites (Fig. 4a). The density of burrowers, which were primarily Tubificidae (Annelida) and Chironomidae (Diptera), increased from $9 \%$ at S1 to $43 \%$ at the mid-and downstream regions of Song Stream, even though the species number was relatively low (as with FFGs). Only burrowers had a strong negative correlation with the percent of cobble substrate $(P<0.05)$, whereas other FHGs were positively correlated to percent cobble (Table 4). 
(a) Odae Stream
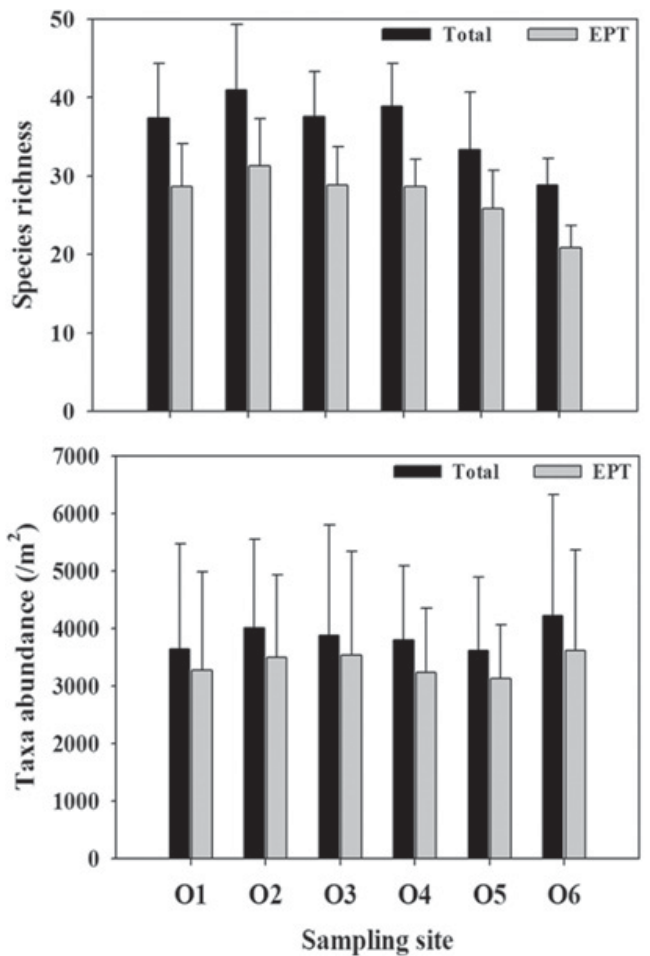

(b) Song Stream
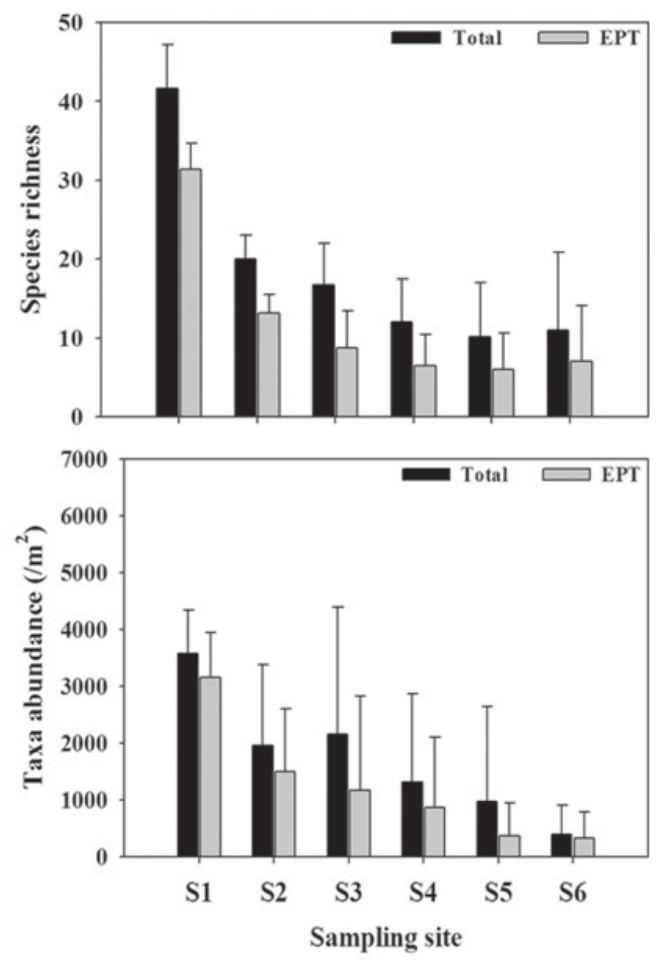

Fig. 3. Mean (standard deviation) of total macroinvertebrate species and EPT (Ephemeroptera + Plecoptera + Trichoptera) taxa in species richness and abundance in Odae Stream (O) and Song Stream (S).

\section{Multivariate analyses}

We used cluster analysis to classify samples from Odae Stream and Song Stream into four groups. Group 1 consisted of samples from the headwaters of both streams $(\mathrm{O} 1$ and S1) and the midstream region of Odae Stream (O2O5); group-2 consisted of samples from the mid- and downstream regions of Odae Stream in the summer; group-3 consisted of samples from the downstream region of Odae Stream (O6) and the middle and lower regions of Song Stream (S2-S6) mainly in the autumn and winter; and group-4 consisted of samples from all sites of Song Stream, except during the winter (Fig. 5). Among these four groups, groups-3 and -4 were well discriminated from groups- 1 and -2 by nutrient content and amount of sediment-related factors. MRPPs indicated significant differences among the four clusters $(A=0.167, P<0.001)$.

CCA ordination indicated a relationship between benthic macroinvertebrate communities and environmental factors (Fig. 6a). In particular, the first two CCA axes explain $17.9 \%$ of the variance of species and environmental variables (eigenvalue of 0.510 for axis- 1 and 0.296 for axis-2). Based on Monte-Carlo analysis, these axes explained significantly more variance than would be expected by chance ( $P=0.02$ for axis- $1, P=0.01$ for axis-2).

CCA axis-1 had a negative correlation with TDS, EC, TN, pH, Chl- $a$, percent sand, turbidity, TP, and BOD, and a positive correlation only with percent cobble. This axis clearly distinguished sites on Song Stream from those on Odae Stream (Fig. 6b). Groups-1 and -2 were mostly on the right part of the ordination along axis-1, whereas groups- 3 and -4 were scattered along the left side of axis-1. The differences in ordination were reflected by differences in community composition. In particular, species such as Limnodrilus gotoi Hatai (Tubificidae), Baetis fuscatus Linnaeus (Ephemeroptera), Antocha sp. (Diptera), and three species of Trichoptera (Hydropsyche valvata Martynov, Cheumatopsyche brevilineata Iwata, and Hydropsyche kozhantschikovi Martynov) characterized samples on the left part of axis-1. In contrast, species such as Epeorus curvatulus Matsumura and Ecdyonurus bajkovae Kluge (Ephemeroptera), Amphinemura sp. and Oyamia coreana Okamoto (Plecoptera), Lepidostoma sp. and Rhyacophila shikotsuensis Iwata (Trichoptera), and Atherix sp. (Diptera) characterized samples on the right part of axis-1 (Fig. 6c).

CCA axis-2 was closely correlated with DO and water temperature due to seasonal variations, and their straight lines pointed in opposite directions (indicating negative correlation). All summer sampling sites with high water temperature were commonly on the bottom of the ordinate, whereas sites from the winter were on the upper part of the ordinate. Some mayfly species such as Serratella setigera (Bajkova), Drunella cryptomeria (Imanishi), Uracanthella rufa (Imanishi), and Iron maculates Tshernova had high negative scores on axis-2, whereas Rhyacophila narvae Navas (Trichoptera), Cincticostella tshernovae (Bajkova) (Ephemeroptera), Taenionema sp., 


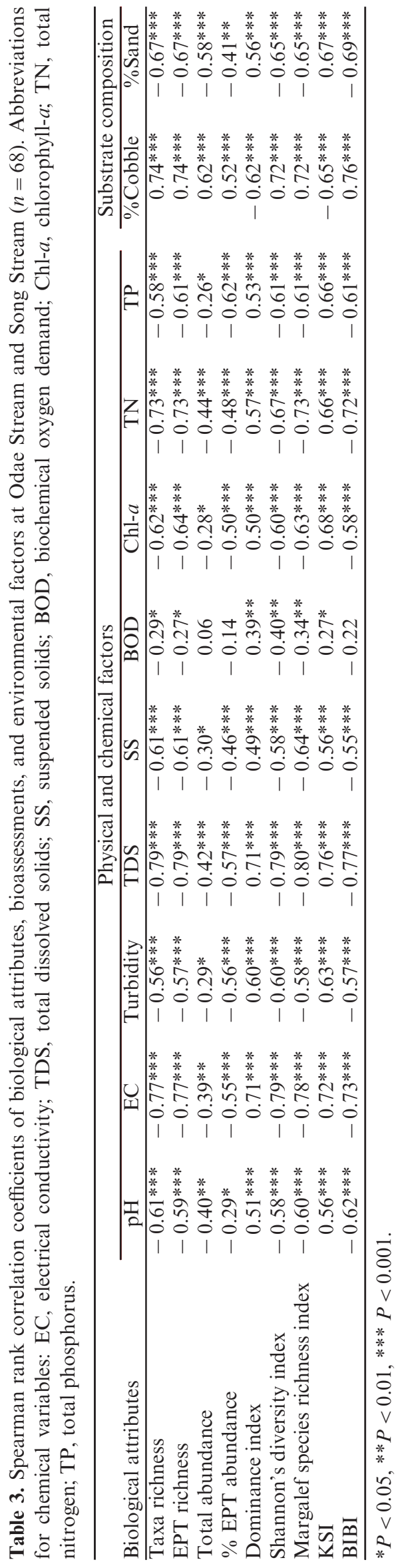

and Protonemura sp. (Plecoptera) had positive scores on axis-2 (Fig. 6b).

\section{Ecological health assessment}

KSI, a measure of organic pollution, ranged from 0.11 to 3.92 in Song Stream and from 0.05 to 0.74 in Odae Stream. A relatively large variation across sampling seasons was evident in the middle region of Song Stream (Fig. 7a). In addition, KSI values were higher at the lower regions (sites S3-S6) than at the upper regions (sites S1 and S2). However, all sampling sites in Odae Stream had very low KSI values, indicating very good ecological health.

Finally, the BIBI of Song Stream and Odae Stream had the same trend as the KSI. However, differences between the two streams were more evident in the BIBI, which had relatively low variance (Fig. 7b). The overall biotic integrity of Song Stream was typically "slightly impaired" to "moderately impaired", although it was classified as "severely impaired" on most occasions at midstream regions (S3-S6). Odae Stream was typically classified as "slightly impaired".

As expected, KSI and BIBI were negatively correlated (Spearman correlation, $r=-0.758, P<0.001)$. KSI was positively correlated with all measured environmental factors measured except BOD and percent cobble, whereas BIBI had the opposite pattern (Table 3). This indicates that increased sedimentation and nutrient levels had adverse effects on overall biotic integrity.

\section{Discussion}

Many researchers have studied the responses of streams and rivers following the transformation of adjacent watersheds from natural forest to agricultural and other uses. These effects generally include degradation in water quality, alteration of physical stream environments, decline in riparian vegetation, enrichment by excessive nutrients, and contamination by toxic materials (Cooper, 1993; Bojsen and Jacobsen, 2003; Crétaz and Barten, 2007).

Highland agricultural activities performed on a steep slope, such as the Song Stream watershed, may trigger significant soil erosion and nutrient enrichment of adjacent streams (Delong and Brusven, 1998; Miserendino and Pizzolon, 2004). In the present study, we found that the markedly higher sediment content of Song Stream was positively correlated with nutrient levels. Moreover, the TP was strongly correlated with the SS, supporting the view that mineral-formed soluble phosphorus associated with sediments is easily lost through soil erosion within an agricultural watershed (Vaithiyanathan and Correll, 1992). In addition, we also found that a large amount of soil erosion was season-dependent, and occurred mostly during the summer monsoon season. The values of turbidity, TDS, and SS in Song Stream were all elevated and fluctuated severely during the summer and early autumn 
Table 4. Spearman rank correlations between principal substrate compositions and functional feeding and habitat groups at all sites on Odae Stream and Song Stream. Significant correlations are indicated with an asterisk $(n=68)$.

\begin{tabular}{|c|c|c|c|c|c|c|c|}
\hline \multirow{2}{*}{\multicolumn{2}{|c|}{ Functional feeding group }} & \multicolumn{2}{|c|}{ Substrate } & \multirow{2}{*}{\multicolumn{2}{|c|}{ Functional habit group }} & \multicolumn{2}{|c|}{ Substrate } \\
\hline & & \multirow{2}{*}{$\begin{array}{c}\text { Cobble } \\
0.17\end{array}$} & \multirow{2}{*}{$\begin{array}{r}\text { Sand } \\
-0.11\end{array}$} & & & Cobble & Sand \\
\hline \multirow{4}{*}{ Collector-filterers } & Species & & & Burrowers & Species & 0.15 & -0.10 \\
\hline & $\%$ Species & $-0.34 * *$ & $0.37 * * *$ & & $\%$ Species & $-0.73 * * *$ & $0.73 * * *$ \\
\hline & Density & $0.31 * *$ & $-0.25^{*}$ & & Density & $0.33 * *$ & $-0.33 * *$ \\
\hline & $\%$ Density & 0.02 & 0.04 & & $\%$ Density & $-0.48 * * *$ & $0.46^{* * *}$ \\
\hline \multirow[t]{4}{*}{ Collector-gatherers } & Species & $0.23^{*}$ & -0.16 & Climbers & Species & $0.74 * * *$ & $-0.72 * * *$ \\
\hline & $\%$ Species & $-0.75^{* * *}$ & $0.77 * * *$ & & $\%$ Species & $0.68 * * *$ & $-0.67 * * *$ \\
\hline & Density & 0.19 & $-0.22^{*}$ & & Density & $0.76 * * *$ & $-0.72 * * *$ \\
\hline & $\%$ Density & $-0.60 * * *$ & $0.57 * * *$ & & $\%$ Density & $0.68 * * *$ & $-0.64 * * *$ \\
\hline \multirow[t]{4}{*}{ Predators } & Species & $0.78 * * *$ & $-0.77 * * *$ & Clingers & Species & $0.73 * * *$ & $-0.68 * * *$ \\
\hline & $\%$ Species & $0.78 * * *$ & $-0.81 * * *$ & & $\%$ Species & $0.34 * *$ & $-0.26^{*}$ \\
\hline & Density & $0.72 * * *$ & $-0.74 * * *$ & & Density & $0.57 * * *$ & $-0.54 * * *$ \\
\hline & $\%$ Density & $0.65 * * *$ & $-0.70 * * *$ & & $\%$ Density & $0.28 * *$ & $-0.25^{*}$ \\
\hline \multirow[t]{4}{*}{ Scrapers } & Species & $0.78 * * *$ & $-0.75^{* * *}$ & Sprawlers & Species & $0.70 * * *$ & $-0.73 * * *$ \\
\hline & $\%$ Species & $0.61 * * *$ & $-0.61 * * *$ & & $\%$ Species & $0.49 * * *$ & $-0.59 * * *$ \\
\hline & Density & $0.75 * * *$ & $-0.72 * * *$ & & Density & $0.76 * * *$ & $-0.78 * * *$ \\
\hline & $\%$ Density & $0.71 * * *$ & $-0.70 * * *$ & & $\%$ Density & $0.58 * * *$ & $-0.62 * * *$ \\
\hline \multirow[t]{4}{*}{ Shredders } & Species & $0.67 * * *$ & $-0.69^{* * *}$ & Swimmers & Species & $0.60 * * *$ & $-0.59 * * *$ \\
\hline & $\%$ Species & $0.468 * * *$ & $-0.52 * * *$ & & $\%$ Species & -0.20 & 0.18 \\
\hline & Density & $0.748 * * *$ & $-0.74 * * *$ & & Density & $0.49 * * *$ & $-0.482 * * *$ \\
\hline & $\%$ Density & $0.580 * * *$ & $-0.57 * * *$ & & $\%$ Density & 0.03 & -0.03 \\
\hline
\end{tabular}

$* P<0.05, * * P<0.01, * * * P<0.001$.

(a) Odae Stream
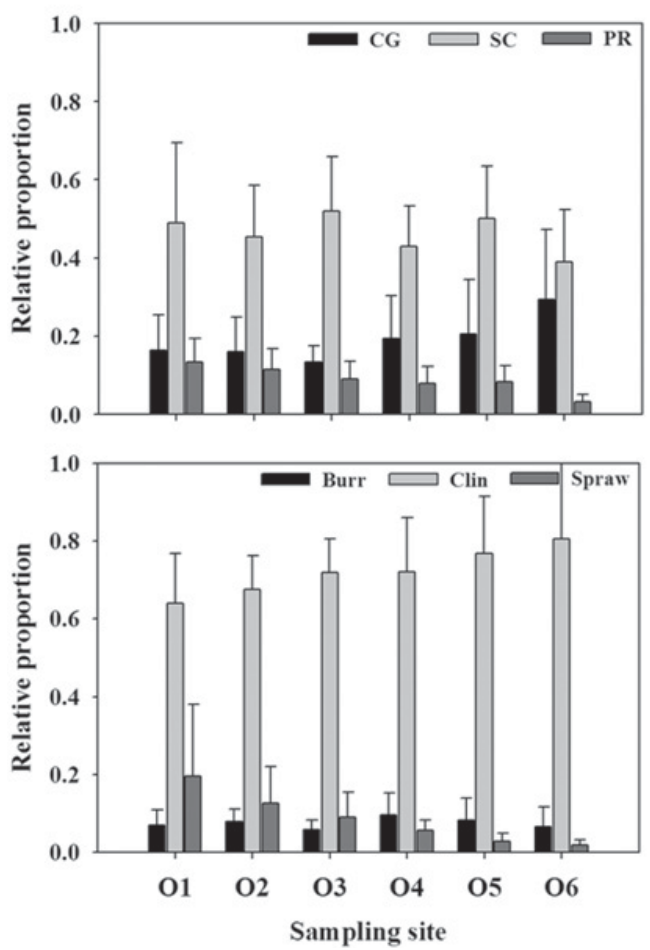

(b) Song Stream
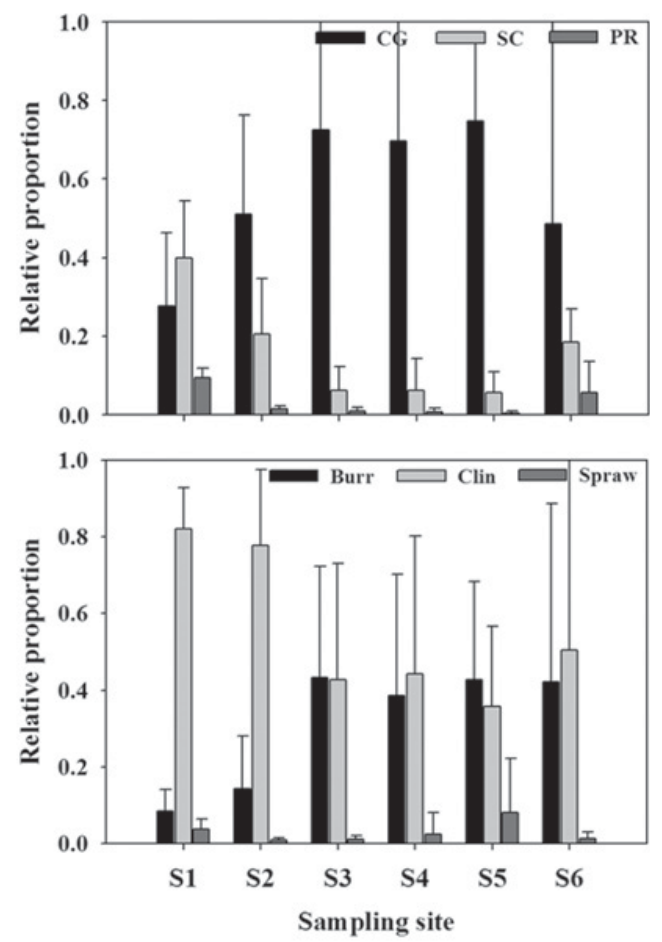

Fig. 4. Mean (standard deviation) proportion of major functional groups in Odae Stream $(\mathrm{O})$ and Song Stream (S). Abbreviations for functional feeding groups: CG, collector-gatherers; SC, scrapers; PR, predators; for functional habit groups: Burr, burrowers; Clin, clingers; Spraw, Sprawlers.

as nutrient levels also increased. In contrast, Odae Stream, which has a mostly undisturbed watershed, exhibited little variation in these factors over the seasons. These results are in agreement with other studies on the relationships of precipitation, SS, and nutrient contents of watersheds (Correll et al., 1999; Crétaz and Barten, 2007). 


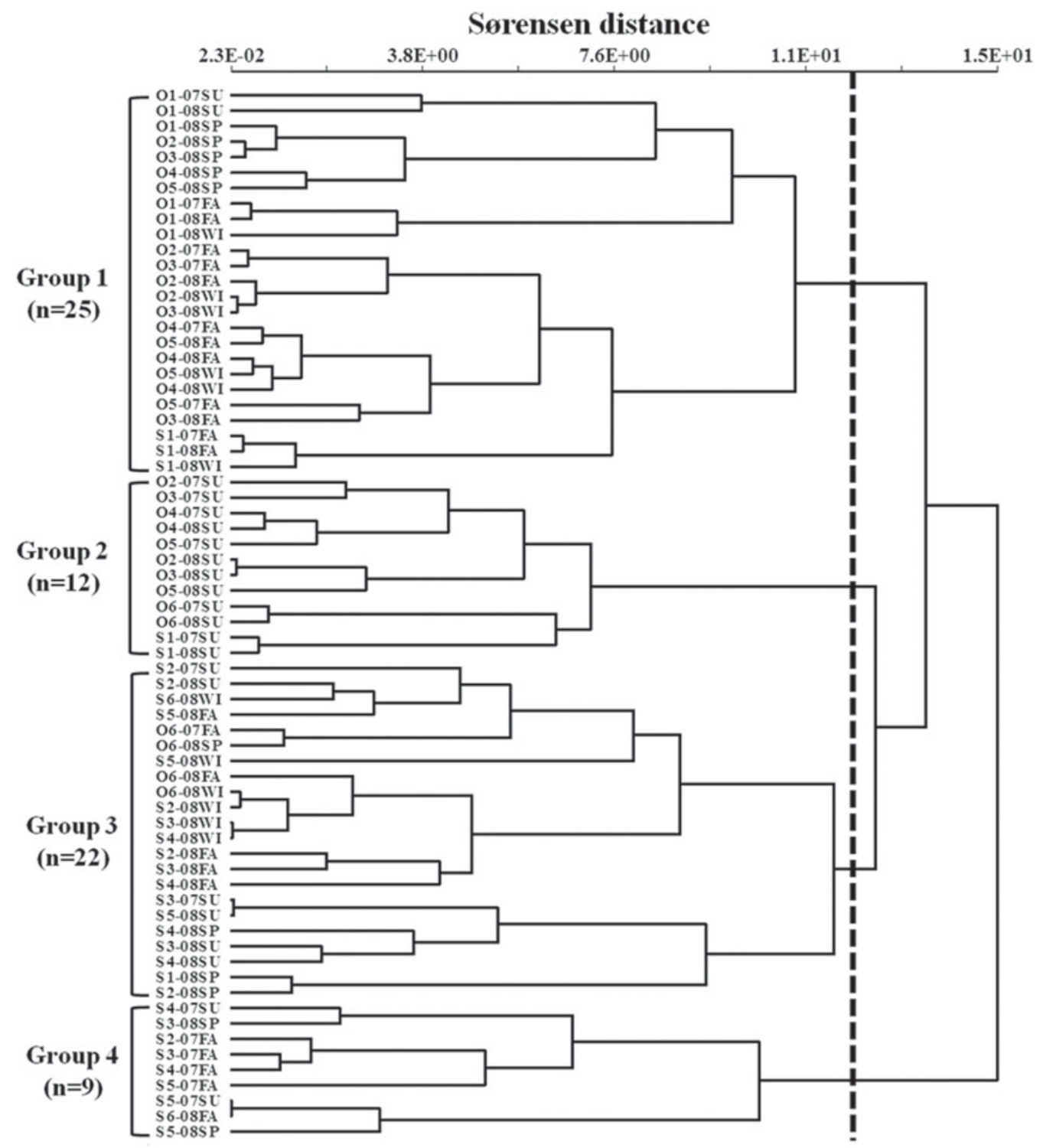

Fig. 5. Dendrogram of macroinvertebrate-based site classification using Sørensen's clustering method. Four site groups are differentiated by the dashed line. Codes for each survey site: sampling site, survey year (07, 2007; 08, 2008), and season (SP, spring; SU, summer; FA, fall; WI, winter).

Well-preserved streamside vegetation, as in the Odae Stream watershed, can prevent soil erosion and nutrient release into adjoining streams because it stabilizes the stream banks. Consequently, streams with preserved watersheds have greater biodiversity and better stream integrity (Osborne and Kovacic, 1993; Sweeney, 1993). A watershed with poor forest cover, such as the Song Stream watershed, is more vulnerable to soil erosion, and this intensifies the deterioration of the water. A recent study which compared a forested reference site with a non-forested region underlined the importance of a riparian forest buffer as modulator of the effects of deforestation on benthic macroinvertebrates in lowland streams (Lorion and Kennedy, 2009). In particular, this previous study reported severe decreases in the diversity and density of benthic communities and the elimination of the most sensitive EPT taxa in pasture area without a riparian forest. In our study, Song Stream had much lower taxa richness and abundance in the downstream regions; in contrast, Odae Stream had little difference in taxa richness and abundance in the upstream and downstream regions. In particular, the poorly vegetated middle regions of Song Stream, which had intensive mixed land uses, had the lowest taxa richness, five times lower than the headwater site (S1) at all survey periods. The communities of the midstream regions of Song Stream were mostly composed of disturbancetolerant colonizers such as tubificids, chironomids, and hydropsychids.

The distribution of sediment along a stream channel determines the morphology of the channel and the structure of habitats that are available to aquatic organisms (Rempel and Church, 2009). Moreover, the size of 


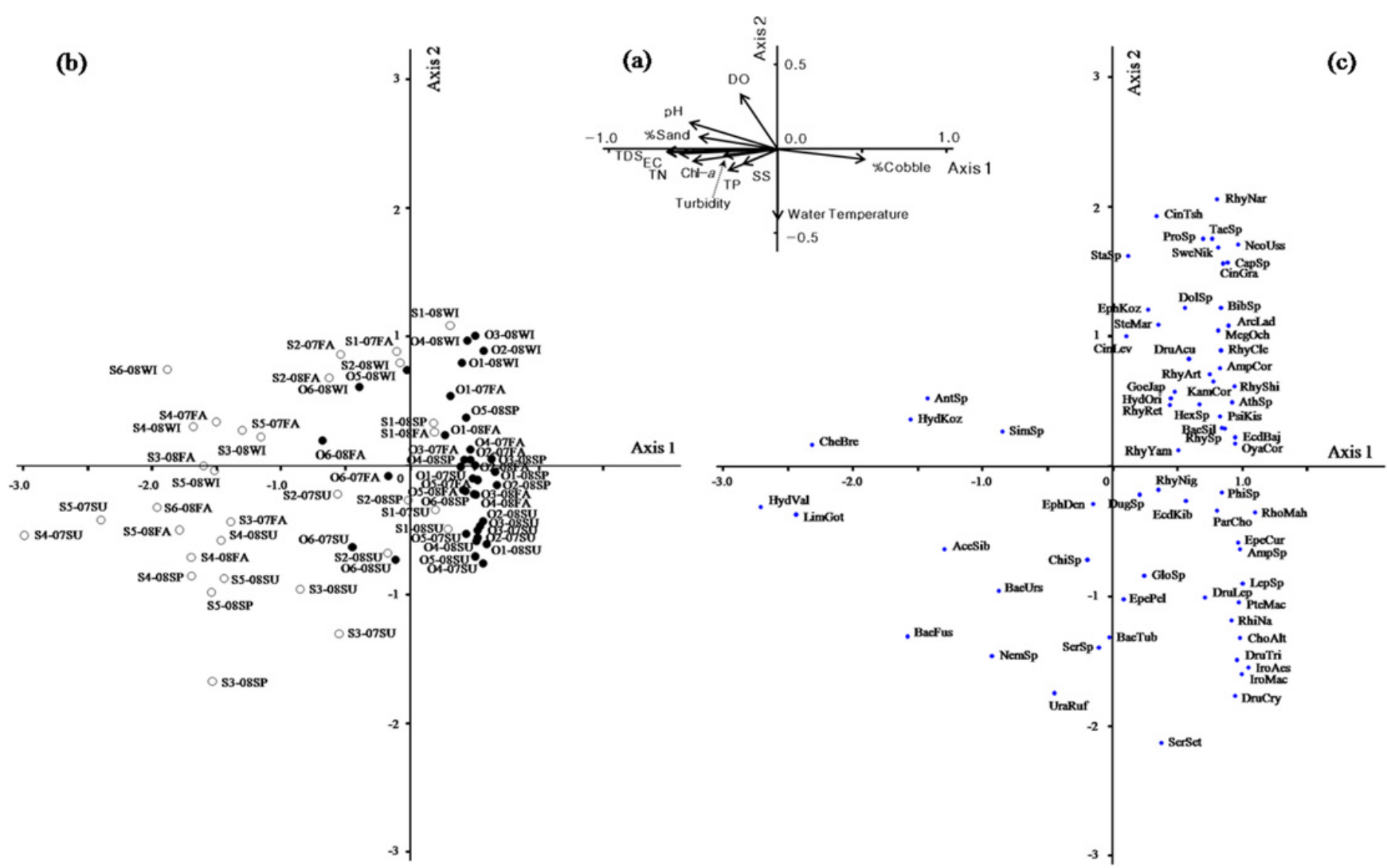

Fig. 6. CCA ordination plots between environmental variables (a) and sampling sites with each sampling season (b) and species that contributed over $0.1 \%$ to taxa abundance (c). Codes for sites: black dark circle, Odae Stream; open black circle, Song Stream. Survey year: 07, 2007; 08, 2008. Seasons: SP, spring; SU, summer; FA, fall; WI, winter. Codes for species are shown in Appendix 1.
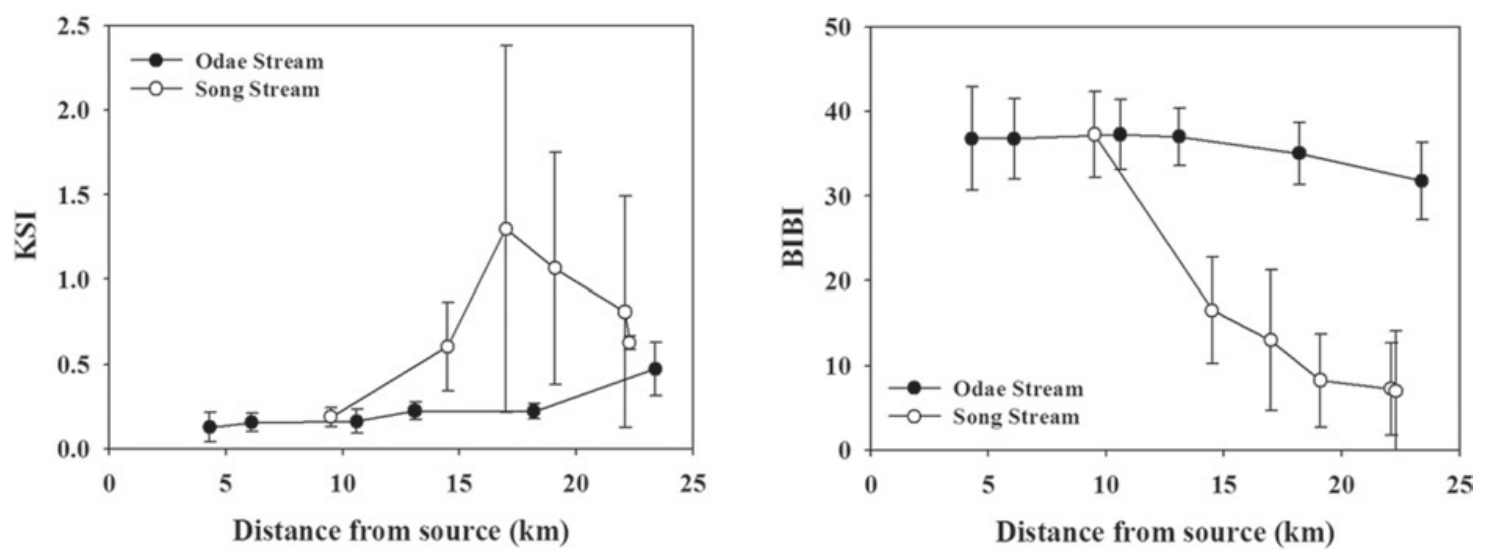

Fig. 7. KSI and BIBI as a function of distance from source in Odae Stream and Song Stream.

the streambed material is often the primary factor that influences benthic community composition and density (Minshall, 1984), although benthic communities are also influenced by water quality, physical settings, and biological interactions. In steep gradient mountain streams, cobbles and boulders are the major structural elements that define habitats (Halwas and Church, 2002), and gravel and smaller sediments are transported downstream. The high diversity and density of macroinvertebrate communities that we observed in Odae Stream might have been sustained by the heterogeneity of coarse substrates, such as boulders, cobbles, and pebbles, which provide suitable habitats for most EPT taxa. The most conspicuous phenomenon at Song Stream, however, was the increase of embedded substrate due to sediment deposition and the consequent alteration of habitat quality, as indicated by the positive correlations of all biological parameters with percent sand in the streambed. Such sediment-induced alterations in macroinvertebrate communities have been documented previously (Lemly, 1982; Miserendino and 
Pizzolon, 2004; Bilotta and Brazier, 2008), although several studies reported an increase in density of some tolerant species or no significant changes (Chutter, 1969; Ryan, 1991).

The functional characteristics of macroinvertebrate communities may help to explain their responses to disturbance, and this information may be useful for local biomonitoring programs (Rabeni et al., 2005). In the present study, we found that species classified as collectorgatherers were more common as percent sand increased and less common as percent cobble increased, whereas the other FFGs showed opposite trends. Scrapers and predators had the most significant reductions in richness and abundance as percent sand increased. Scrapers are intolerant to degradation in water quality because they mainly consume attached algae that grow on the cobbles and pebbles of undisturbed streams (Vannote et al., 1980; Merritt and Cummins, 1996; Rabeni et al., 2005). Predators also had a positive correlation with percent cobble. The proportion of predators is generally low and changes little along the length of rivers (Vannote et al., 1980). However, considering the environmental characteristics of both of our mountain streams, we expected a decline in richness and density of predators as disturbance increased, because the predators we recorded included many intolerant species, such as stoneflies and rhyacophilid caddisflies. Although our observed relationships of collector-filterers with physical variables were very weak or not significant, their species richness somewhat paralleled the nutrient levels. The densely forested headwaters usually include a low proportion of collector-filterers due to large inputs of allochthonous organic matter, particularly during autumn and throughout leaf fall (Anderson and Sedell, 1979; Vannote et al., 1980). The collector-filterers that we observed in Song Stream, such as hydropsychid caddisflies, gradually increased in downstream regions, but these occurred in low proportions in Odae Stream.

Benthic macroinvertebrate species can be categorized as attachment types (e.g., caddisflies), which live on rocky surfaces, or burrowing types (e.g., worms), which inhabit cohesive soft sediments (Merritt and Cummins, 1996). The greatest diversity occurs in communities of attachment types with cobble and gravel riffles, whereas less diverse assemblages of burrowing types inhabit cohesive soft sediments (Williams and Mundie, 1978). In the present study, most functional habit groups were adversely affected by a high percentage of sand, but burrowers increased as percent sand increased (Table 4). Moreover, clingers and sprawlers, including many intolerant EPT species, prefer large-sized substrates and riffle habitats. But increased sedimentation was likely to favor burrowing species in Song Stream, even though there was a decline in water quality.

Cluster analysis and CCA, in agreement with the results of our correlation analysis, indicated distinct differences in the macroinvertebrates of Song Stream and Odae Stream. Sedimentation, nutrient levels, and types of substrates were the main environmental factors controlling the distribution of macroinvertebrates. There were also different distributions of functional feeding groups. Stoneflies (Plecoptera), Heptageniidae and Ephemerellidae (Ephemeroptera), and Rhyacophilidae (Trichoptera) are very sensitive to disturbance, and these taxa are mainly limited to mountain streams with fastflowing and oxygen-rich water (McCafferty, 1981). However, Similium (Diptera), H. kozhantschikovi, $H$. valvata, and C. brevilineata (Trichoptera), all of which are collector-filterers, have the opposite trend. These results agree with a previous study which showed that two genera of Hydropsychidae (Hydropsyche and Cheumatopsyche) were tolerant to polluted and nutrientrich streams (Mackay and Wiggins, 1979). The distribution of FHGs had the same trend in CCA, in that burrowers and sprawlers had opposite tendencies (Fig. 6c). Unlike our correlation results, clingers, which prefer fast-flowing current, were scattered and not discriminated by CCA ordination, despite their high taxa richness $(55.6 \%$ of total species number). This may be because our samples of benthic macroinvertebrates were confined to riffle habitats.

Finally, our results demonstrated that alterations of the physical and chemical conditions of a stream disrupt macroinvertebrate communities and have detrimental effects on overall stream health, as indicated by our KSI and BIBI measurements. KSI and BIBI indicated that Song Stream had "good to fair" status in terms of organic pollution and was "moderately to severely impaired" in biological integrity. It thus appears that a deterioration of habitat quality in Song Stream led to a shift in the composition of macroinvertebrate communities from disturbance-sensitive species to disturbance-tolerant species.

In conclusion, the Song Stream watershed has experienced a decline in ecological integrity, primarily because of substantial degradation of stream habitats rather than deterioration in water quality. Thus, examination of benthic macroinvertebrate communities may be able to differentiate physical disturbances from chemical disturbances. Our findings indicate that the physical factors of streams, in addition to water quality, should be considered in the assessment of stream ecosystems.

Acknowledgements. This study was financially supported by the Ministry of Environment and the National Institute of Environmental Research (Korea). The authors would like to thank all the survey members involved in the project for their help in the samplings and analyses. We also thank the reviewers for their help in improving the scientific quality of the manuscript.

\section{References}

Anderson N.H. and Sedell J.R., 1979. Detritus processing by macroinvertebrates in stream ecosystems. Annu. Rev. Entomol., 24, 351-377.

APHA, 2001. Standard methods for the examination of water and wastewater, American Public Health Association, 21st edn., APH-AWW-WEF, Washington, DC. 
Barbour M.T., Gerritsen J., Snyder B.D. and Stribling J.B., 1999. Rapid bioassessment protocols for use in streams and wadeable rivers: periphyton, benthic macroinvertebrates, and fish, 2nd edn., EPA 841-B-99-002, U.S. Environmental Protection Agency, Office of Water, Washington, DC.

Bilotta G.S. and Brazier R.E., 2008. Understanding the influence of suspended solids on water quality and aquatic biota. Water Res., 42, 2849-2861.

Bojsen B.H. and Jacobsen D., 2003. Effects of deforestation on macroinvertebrate diversity and assemblage structure in Ecuadorian Amazon streams. Arch. Hydrobiol., 158, $317-$ 342.

Brierley G.J. and Fryirs K.A., 2005. Geomorphology and river management: applications of the river styles framework, Blackwell Publishing, Oxford, UK, 398 p.

Broekhuizen N., Parkyn S. and Miller D., 2001. Fine sediment effects on feeding and growth in the invertebrate grazers Potamopyrgus antipodarum (Gastropoda, Hydrobiidae) and Dealeatidium sp. (Ephemeroptera, Leptophlebiidae). Hydrobiologia, 457, 125-132.

Chutter F.M., 1969. The effects of silt and sand on the invertebrate fauna of streams and rivers. Hydrobiologia, 34, 57-76.

Cooper C.M., 1993. Biological effects of agriculturally derived surface water pollutants on aquatic systems - a review. J. Environ. Qual., 22, 402-408.

Correll D.L., Jordan T.E. and Weller D.E., 1999. Precipitation effects on sediment and associated nutrient discharges from Rhode River watersheds. J. Environ. Qual., 28, 1897-1907.

Crétaz A.L. and Barten P.K., 2007. Land use effects on streamflow and water quality in the northeastern United States, CRC Press, Boca Raton, FL, 319 p.

Cummins K.W., 1962. An evaluation of some techniques for the collection and analysis of benthic samples with special emphasis on lotic waters. Am. Midl. Nat., 67, 477-504.

Delong M.D. and Brusven M.A., 1998. Macroinvertebrate community structure along the longitudinal gradient of an agriculturally impacted stream. Environ. Manage., 22, 445-457.

DIN 38410, 1990. Part 2, Biological-ecological analysis of water (group M); determination of the saprobic index (M2), German standard methods for the examination of water, waste water, and sludge.

Halwas K. and Church M., 2002. Channel units in small, high gradient streams on Vancouver Island, British Columbia. Geomorphology, 43, 243-256.

Harding J.S., Young R.G., Hayes J.W., Shearer K.A. and Stark J.D., 1999. Changes in agricultural intensity and river health along a river continuum. Freshwater Biol., 42, 345-357.

Karr J.R., Fausch K.D., Angermeier P.L., Yant P.R. and Schlosser I.J., 1986. Assessing biological integrity in running waters: a method and its rationale. Special Publication 5, Illinois Natural History Survey, Champaign, IL.

Kerans B.L. and Karr J.R., 1994. A benthic index of biotic integrity (BIBI) for rivers of the Tennessee valley. Ecol. Appl., 4, 768-785.

KMA, 2009. The meteorological yearbook in Korea, Korea Meteorological Administration (in Korean).

Kwon O.K., Min D.K., Lee J.R., Lee J.S., Je J.G. and Choe B.L., 2001. Korean mollusks with color illustration, Hanguel Publishing Company, Seoul, 332 p. (in Korean).
Lemly D.A., 1982. Modification of benthic insect communities in polluted streams: combined effects of sedimentation and nutrient enrichment. Hydrobiologia, 87, 229-245.

Lorion C.M. and Kennedy B.P., 2009. Relationships between deforestation, riparian forest buffers and benthic macroinvertebrates in neotropical headwater streams. Freshwater Biol., 54, 165-180.

MacKay R.J. and Wiggins G.B., 1979. Ecological diversity in Trichoptera. Ann. Rev. Entomol., 24, 185-208.

MAF, 2007. Development of environment-friendly erosion control techniques for ecosystem conservation in torrent, The Ministry of Agriculture and Forestry, Korea (in Korean).

Margalef R., 1958. Information theory in ecology. Gen. Syst., 3, 36-71.

McCafferty W.P., 1981. Aquatic entomology, Jones and Bartlett Inc., Boston, 448 p.

McCune B. and Mefford M.J., 1999. Multivariate analysis of ecological data (Version 4.25), MjM Software, Gleneden Beach, OR.

Merritt R.W. and Cummins K.W., 1996. An introduction to the aquatic insects of North America, 3rd edn., Kendall/Hunt Publishing, Dubuque, IA.

Minshall G.W., 1984. Aquatic insect-substratum relationships. In: Resh V.H. and Rosenberg D.M. (eds.), The Ecology of Aquatic Insects, Praeger, New York, 358-400.

Miserendino N.L. and Pizzolon L.A., 2004. Interactive effects of basin features and land-use change on macroinvertebrate communities of headwater streams in the Patagonian Andes. River Res. Appl., 20, 967-983.

MOE, 2000. The second guidelines for nation-wide natural environment survey in Korea, The Ministry of Environment, Korea (in Korean).

MOE, 2007. The management plan for non-point source pollution in the watershed of Lake Doam, The Ministry of Environment, Korea, 18 p. (in Korean).

MOE/HERC, 2010. Survey on the environment and ecosystem of lakes in the Han River system, The Ministry of Environment/Han River Environment Research Center, Korea (in Korean).

MOE/NIER, 2006. Study on development of methods for synthetic assessment of water environment (III) - survey and evaluation of aquatic ecosystem health, The Ministry of Environment/National Institute of Environmental Research, Korea (in Korean).

MOE/NIER, 2008. Survey and evaluation of aquatic ecosystem health in Korea, The Ministry of Environment/National Institute of Environmental Research, Korea (in Korean).

Osborne L.L. and Kovacic D.A., 1993. Riparian vegetated buffer strips in water-quality restoration and stream management. Freshwater Biol., 29, 243-258.

Quinn J.M. and Stroud M.J., 2002. Water quality and sediment and nutrient export from New Zealand hill-land catchments of contrasting land use. N. Z. J. Mar. Freshwater Res., 36, 409-429.

Quinn J.M., Davies-Colley R.J., Hickey C.W., Vickers M.L. and Ryan P.A., 1992. Effects of clay discharges on streams. Hydrobiologia, 248, 235-247.

Rabeni C.F., Doisy K.E. and Zweig L.D., 2005. Stream invertebrate community functional responses to deposited sediment. Aquat. Sci., 67, 395-402. 
Rempel L.L. and Church M., 2009. Physical and ecological response to disturbance by gravel mining in a large alluvial river. Can. J. Fish. Aquat. Sci., 66, 52-71.

Rier S.T. and King D.K., 1996. Effects of inorganic sedimentation and riparian clearing on benthic community metabolism in an agriculturally-disturbed stream. Hydrobiologia, 339, 111-121.

Rosenberg D.M. and Resh V.H., 1993. Freshwater Biomonitoring and Benthic Macroinvertebrates, Chapman and Hall, New York, 488 p.

Ryan P.A., 1991. Environmental effects of sediment on New Zealand streams: a review. N. Z. J. Mar. Freshwater Res., 25, 207-221.

Shannon C.E. and Weaver W., 1949. The Mathematical Theory of Communication, University of Illinois Press, Urbana, IL.

Smith D.G., 2001. Pennak's Freshwater Invertebrates of the United States - Porifera to Crustacea, John Wiley and Sons, New York, $638 \mathrm{p}$.

StatSoft Inc., 2004. STATISTICA (data analysis software system), Version 7, http://www.statsoft.com.

Stewart J.S., Wang L., John L., Horwatich J.A. and Bannerman R., 2001. Influence of watershed, riparian-corridor, and reach-scale characteristics on aquatic biota in agricultural watersheds. J. Am. Water Resour. Assoc., 37, 1475-1487.

Suren A.M. and Jowett I.G., 2001. Effects of deposited sediment on invertebrate drift: an experimental study. N. Z. J. Mar. Freshwater Res., 35, 725-737.

Sweeney B.W., 1993. Effects of streamside vegetation on macroinvertebrate communities of White Clay Creek in eastern North America. Proc. Acad. Natl. Sci. Phila., 144, 291-340.
Ulrich K.E., Burton T.M. and Oemke M.P., 1993. Effects of whole-tree harvest on epilithic algal communities in headwater stream. J. Freshwater Ecol., 8, 83-92.

Vaithiyanathan P. and Correll D.L., 1992. The Rhode River watershed: phosphorus distribution and export in forest and agricultural soils. J. Environ. Qual., 21, 280-288.

Vannote R.L., Minshall G.W., Cummins K.W., Sedell J.R. and Cushing C.E., 1980. The river continuum concept. Can. J. Fish. Aquat. Sci., 37, 130-137.

Waters T.F., 1995. Sediment in streams: sources, biological effects and control, American Fisheries Society Monograph 7, American Fisheries Society, Bethesda, MD.

Williams D.D. and Mundie J.H., 1978. Substrate size selection by stream invertebrates and the influence of sand. Limnol. Oceanogr., 23, 1030-1033.

Won D.H., Kwon S.J. and Jun Y.C., 2005. Aquatic insects of Korea, Korea Ecosystem Service Publishing Company, Seoul, Korea (in Korean).

Won D.H., Jun Y.C., Kwon S.J., Hwang S.J., Ahn K.G. and Lee J.K., 2006. Development of Korean Saprobic Index using benthic macroinvertebrates and its application to biological stream environment assessment. J. Korean Soc. Water Qual., 22, 768-783 (in Korean).

Wood P.J. and Armitage P.D., 1997. Biological effects of fine sediment in the lotic environment. Environ. Manage., 21, 203-217.

Yoon I.B., 1995. An illustration of aquatic insects in Korea, Jeonghaengsa Publishing Company, Seoul, Korea (in Korean).

Zelinka M. and Marvan P., 1961. Zur präzisierung der biologische klassifikation der reinheit fliessender gewässer. Arch. Hydrobiol., 57, 389-407.

Appendix 1. Names and abbreviations of 68 species that contributed to more than $0.1 \%$ of total density for CCA.

\begin{tabular}{|c|c|c|c|}
\hline Species name & Abbreviation & Species name & Abbreviation \\
\hline Phylum Platyhelminthes & & Protonemura sp. & ProSp \\
\hline Dugesia sp. & DugSp & Capnia sp. & CapSp \\
\hline Phylum Annelida & & Rhopalopsole mahunkai Zwick & RhoMah \\
\hline Limnodrilus gotoi Hatai & LimGot & Pteronarcys macra Ra, Baik, and Cho & PteMac \\
\hline Phylum Arthropoda & & Megarcys ochracea Klapalek & MegOch \\
\hline Class Insecta & & Stavsolus sp. & StaSp \\
\hline Order Ephemeroptera & & Kamimuria coreana Ra, Kim, Kang, and Ham & KamCor \\
\hline Acentrella sibirica Kazlauskas & AceSib & Oyamia coreana Okamoto & OyaCor \\
\hline Baetiella tuberculata (Kazlauskas) & BaeTub & Sweltsa nikkoensis (Okamoto) & SweNik \\
\hline Baetis fuscatus Linnaeus & BaeFus & Order Diptera & \\
\hline Baetis silvaticus Kluge & BaeSil & Antocha sp. & AntSp \\
\hline Baetis ursinus Kazlauskas & BaeUrs & Hexatoma sp. & HexSp \\
\hline Cinygmula grandifolia Tshernova & CinGra & Simulium sp. & $\operatorname{SimSp}$ \\
\hline Ecdyonurus bajkovae Kluge & EcdBaj & Chironomidae spp. & ChiSp \\
\hline Ecdyonurus kibunensis Imanishi & EcdKib & Bibiocephala sp. & BibSp \\
\hline Epeorus curvatulus (Navas) & EpeCur & Philorus sp. & PhiSp \\
\hline Epeorus pellucidus Kluge & EpePel & Atherix sp. & AthSp \\
\hline Iron aesculus (Imanishi) & IroAes & Order Trichoptera & \\
\hline Iron maculates Tshernova & IroMac & Rhyacophila articulate Morton & RhyArt \\
\hline Rhithrogena na & RhiNa & Rhyacophila clemens Tsuda & RhyCle \\
\hline Choroterpes altioculus Kluge & ChoAlt & Rhyacophila narvae Navas & RhyNar \\
\hline Paraleptophlebia chocolate Imanishi & RarCho & Rhyacophila nigrocephala Iwata & RhyNig \\
\hline Cincticostella levanidovae (Tshernova) & CinLev & Rhyacophila retracta Martynov & RhyRet \\
\hline Cincticostella tshernovae (Bajkova) & CinTsh & Rhyacophila shikotsuensis Iwata & RhyShi \\
\hline Drunella aculea (Allen) & DruAcu & Rhyacophila yamanakensis Iwata & RhyYam \\
\hline Drunella cryptomeria (Imanishi) & DruCry & Rhyacophila sp. & RhySp \\
\hline
\end{tabular}


Appendix 1. (Continued.)

\begin{tabular}{llll}
\hline Species name & Abbreviation & \multicolumn{1}{c}{ Species name } & Abbreviation \\
\hline Drunella lepnevae (Tshernova) & DruLep & Glossosoma sp. & GloSp \\
Drunella triacantha (Tshernova) & DruTri & Dolophilodes sp. & SteMar \\
Ephemerella dentate Bajkova & EphDen & Stenopsyche marmorata Navas & ArcLad \\
Ephemerella kozhovi Bajkova & EphKoz & Arctopsyche ladogensis Kolenati & CheBre \\
Serratella setigera (Bajkova) & SerSet & Cheumatopsyche brevilineata Iwata & HydKoz \\
Serratella sp. & SerSp & Hydropsyche kozhantschikovi Martynov & HydOri \\
Uracanthella rufa (Imanishi) & UraRuf & Hydropsyche orientalis Martynov & HydVal \\
Order Plecoptera & & Hydropsyche valvata Martynov & GoeJap \\
Taenionema sp. & TaeSp & Goera japonica Banks & NeoUss \\
Amphinemura coreana Zwick & AmpCor & Neophylax ussuriensis Martynov & LepSp \\
Amphinemura sp. & AmpSp & Lepidostoma sp. & PsiKis \\
Nemoura sp. & NemSp & Psilotreta kisoensis Iwata & \\
\hline
\end{tabular}

